\title{
14. Ģimenes politikas attīstība
}

\author{
Līga Āboliṇa
}

Latvijā, līdzīgi kā citviet Eiropā, ǵimenes atbalsta politikai, īpaši pēdējos gados, tiek pievērsta pastiprināta uzmanība. Savu nozīmīgumu tā iemantojusi tādu mūsdienu sabiedrībā notiekošo pārmaiṇu dēḷ kā, piemēram, sabiedrības novecošana, iedzīvotāju skaita samazināšanās, ǵimeṇu skaita samazināšanās, zemie dzimstības rādītāji, ğimenes tipu diversifikācija, kā arī sieviešu ìpatsvara un lomas pieaugums darba tirgū. Līdz ar to pieaug nepieciešamība saskaņot darba un ǵimenes dzīvi.

Nepieciešamība atsevišķi izvērtēt ǵimenes atbalsta politiku, lai veicinātu ar dzimstību, ǵimeṇu veidošanos un ar stabilitāti saistītu mērķu sasniegšanu, ir vēsturiski priekšnosacīta un sakṇojas demogrāfiskās pārejas teorijā. Holandiešu zinātnieks $D$. van de Kaa un beḷǵu zinātnieks $R$. Lesthaeghe jau 1986. gadā norādīja uz savstarpēji saistītām izmaiņām dzimstībā, ğimenes veidošanas procesā un attiecībās starp partneriem, kuras sākušās pagājušā gadsimta 60. gadu beigās daudzās Rietumeiropas un Ziemeḷeiropas valstīs. Šìs izmaiṇas bija cieši saistītas ar būtiskām vērtību sistēmas pārmaiṇām, kuras attiecas uz ğimenes dzīvi un bērniem. Tika atzīmēts, ka, palielinoties kontraceptīvo līdzekḷu pieejamībai un ievērojami samazinoties dzimstībai, nesasniedzot paaudžu nomaiņas slieksni, vājinās tradicionālās ǵimenes kā institūta nozīme sabiedrībā. Tam par pamatu bija uzskats, ka rūpnieciski attīstītās valstis ir sasniegušas jaunu posmu demogrāfiskajā attīstībā, kuram raksturīga pilnīga dzimstības kontrole. Tā kā pāriem zuda motivācija radīt vairāk nekā divus bērnus, arī dzimstība samazinājās zem paaudžu nomaiṇai nepieciešamā sliekšņa. Lai gan piel̦aujams, ka zināma nozīme bija arī bērna radīšanas atlikšanai, novērojumi liecināja, ka joprojām saglabājas zems dzimstības līmenis, tādējādi radot jaunu demogrāfiskā līdzsvara trūkumu. Pārmaiņas sabiedrībā ietekmē jēdziena "ǵimene" saturu un ǵimenes atbalsta politikas attīstību un redzējumu par nepieciešamajiem atbalsta pasākumiem.

Laika gaitā ǵimenes politikas jēdziens un saturs ir plaši analizēts vairāku dažādu nozaru pētnieku zinātniskajos darbos. Pēc kanādiešu sociologa Ešlemana (J. R. Eshleman) domām, ǵimenes politika ir sociālās politikas atsevišķāā priekšmetiskā joma, kas orientēta uz gimeni un saistīta ar virkni tādu publisko 
politiku îstenošanu, kuru mērķis ir veicināt ǵimeņu veidošanu un attīstību, nodrošinot ǵimenēm pietiekamus ienākumus, nodarbinātības apstākḷus un publiskos pakalpojumus. G̦imenes politikai nav izsmel̦ošas definīcijas, un tā pārsvarā reducējama uz ǵimenes struktūru (angḷu - family composition) veidošanu, atbalsta pasākumiem ǵimenēm ar bērniem (pabalstiem, pakalpojumiem un nodarbinātību) un bērnu attīstību (izglìtîbu, veselību, sociālo drošību un tiesību aizsardzību) (Eshleman, Bulcroft, 1991). G̦imenes politika parasti ir integrēta labklājības sistēmā (Schubert et al., 2009). Tā kā gimenes politika ir viena no jaunākajām politikas jomām un tā ir attīstījusies vēlāk un lēnāk nekā lielākā daḷa sociālo politiku, tai ir raksturīga zema institucionalizācijas pakāpe (Blum, Rille-Pfeiffer, 2009, 3).

Savukārt Groningenas Universitātes (Nīderlande) profesore demogrāfe A. Gauthier uzskata, ka ǵimenes politika ir dažādu politikas jomu, kas vērstas uz gimeni ar bērniem, apvienojums un tās mērḳis ir paaugstināt labklājības līmeni. Ģimenes politikai vairāk nekā jebkurai citai politikas jomai piemìt pārnozaru raksturs, tā ietver dažādus tematus, kā nodarbinātība, izglìtība, mājoklis, kas visi zināmā mērā ietekmē ğimeni (Gauthier, Anne, 1999). Viskonsinas-Medisonas Universitātes (ASV) profesore un gimenes politikas speciāliste Bogenšneidere ( $K$. Bogenschneider) ǵimenes politiku definē kā valdības aktivitātes, kas veiktas, lai atbalstītu gimenes, uzlabotu gimenes locekḷ labklājību un stiprinātu gimenes attiecības (Robila, 2014, 3). N̦emot vērā goimenes centrālo lomu sabiedrībā, ǵimenes politikas izstrādei, ieviešanai un novērtēšanai vajadzētu būt vienai no svarīgākajām politiskās dienaskārtības sastāvdaḷām. Tas ir komplekss process, kas prasa savstarpēji koordinētu multidisciplināras komandas darbu. Šādu komandu veido dažādas ieinteresētās puses: valdības un politikas eksperti, zinātnieki, nevalstisko organizāciju pārstāvji un arī aktīvas ǵimenes, kas iesaistās sabiedriskās domas veidošanā.

Tāpat gimenes politika ir kā iedzīvotāju politikas, tā arī demogrāfiskās politikas ${ }^{1}$ sastāvdaḷa, jo tās aktīva vai, gluži pretēji, pasīva ìstenošana ietekmē iedzīvotāju kustības procesus. Demogrāfiskā politika savukārt ietilpst valsts sociālās politikas sastāvā. Tā ir pasākumu kopums demogrāfisko procesu un struktūru apzinātai izmainišanai, lai sasniegtu vēlamo stāvokli (Sociālā darba terminoloǵijas vārdnīca, 2000, 44). Iedzīvotāju politika ir instruments, ar kura palīdzību valdība, iesaistot arī nevalstisko sektoru, tieši vai netieši ietekmē demogrāfisko attīstību. Šis instrumentārijs ietver juridiskus līdzekḷus, administratīvas programmas un citas valsts institūciju darbības, lai panāktu izmainas

Ar demogrāfisko politiku saprot valsts varas institūciju un sabiedrisko organizāciju mērḳtiecīgu rīcību iedzīvotāju kustības procesu regulēšanai, īstenojot sociālus, ekonomiskus, juridiskus u. c. pasākumus, savukārt iedzīvotāju politikai ir plašāks diapazons, tā ir attiecināma uz esošās un gaidāmās iedzivotāju attīstības ietekmēšanu (Demogrāfisko terminu skaidrojošā vārdnīca, 2001, 26, 54). 
pašreizējās iedzìvotāju attīstības tendencēs un nodrošinātu valsts ilgtspēju un labklājību (Demeny, 2003, 752; Poston, Bouvier, 2010, 338 u. c.), un iedzīvotāju politikā svarīga nozīme ir ğimenes dimensijai. Autores ieskatā ǵimenes politika pēc būtības ir atsevišķa valsts politikas joma, tomēr, tā kā tā ir gan demogrāfiskās, gan sociālās politikas sastāvdaḷa, tā nevar būt no pārējās sociālās politikas atrauts, patstāvīgs process (14.1. attēls).

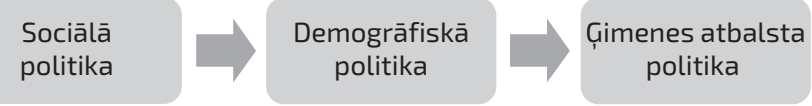

14.1. attēls. G̦imenes atbalsta politikas vieta hierarhijā

Galvenā ǵimenes politikas īpatnība ir tās pārnozaru un starpdisciplinārais raksturs, un tās īstenošana līdztekus sociālās drošības, pabalstu, pensiju un citām politikām ietekmē demogrāfiskos procesus. Tiek uzskatīts, ka pastāv vairākas jomas, uz kurām iedarbojoties var ietekmēt iedzīvotāju procesus, tajā skaitā laulātîbu, dzimstību, mirstību un migrāciju. Tādējādi ikvienai politikai, kas izstrādāta, lai ietekmētu demogrāfiskos procesus, jābūt vērstai uz vismaz vienu no minētajām politikām. Nepieciešamība pēc aktīvas demogrāfiskās politikas dažādos laika posmos un dažādās valstīs var nebūt aktuāla, arī demogrāfiskās politikas mērḳi var būt atšķirīgi. Piemēram, dzimstību ietekmējošās politikas var iedalît divās grupās - ir pronatalistiskas politikas un antinatalistiskas politikas (Poston et al., 2010, 351). Antinatalistiska pieeja politikā raksturīga valstīm, kurām nav nepieciešams iedzìvotāju skaita pieaugums, piemēram, ASV, Meksikai, Indijai, Vjetnamai, Ēǵiptei u. c. Savukārt pronatalistiskas politikas virziena ievērošana ir raksturīga ǵimenes politikas jomām Eiropā, ņemot vērā samērā straujo novecošanu un zemo dzimstību, kas lielākajā dạā attīstīto valstu nesasniedz to līmeni, kurš nepieciešams vienkāršai paaudžu maiņai. Šãda politika parasti ietver trīs virzienus - dzimstības veicināšanu, uz ǵimeni vērstus atbalsta pasākumus, piemēram, ǵimenes pabalstus, kā arī radikālākos risinājumos pat abortu aizliegumus un kontraceptīvo līdzekḷu pieejamības ierobežošanu.

Ungāru izcelsmes pētnieks norādījis (Demeny, 2003, 26), ka pronatalistiskas politikas mērķim būtu jābūt plašākam par vienkāršu dzimstības veicināšanu. Pronatalistiskai politikai jābūt vērstai arī uz atbalstu ǵimenēm, lai bērniem tiktu nodrošināta vislabākā iespēja izaugt par produktīviem un atbildīgiem sabiedrības locekḷiem. Bet Austrijas izcelsmes pētnieks ir uzsvēris, ka pronatalistiskas politikas pamatā ir vienlīdzīgu iespēju radīšana un atbalsts sievietēm, lai tās spētu apvienot bērnu aprūpi un audzināšanu ar nodarbinātîbu (Lutz et al., 2003). Atkarībā no katras valsts nacionālās kultūras, sociālajiem paradumiem 
un tradīcijām arī gimenes politikas akcenti katrā valstī ir atškirīgi (Lutz et al., 2003). Eiropā mūsdienās par vienu no visveiksmīgākajām tiek uzskatīta Francijas pieredze, kurā ir augsts strādājošu sieviešu īpatsvars un vienlaikus arī vieni no augstākajiem dzimstības rādītājiem, jo ir izveidota visaptveroša bērnu pieskatîšanas un aprūpes sistēma. Eiropā popularitāti iemantojusi arī Ziemeḷvalstu pieeja, bērnu aprūpē un audzināšanā attīstot dzimumneitrālu pieeju un tādējādi nodrošinot atbalstu ǵimenei kopumā un līdzvērtīgus atbalsta pasākumus kā mātei, tā tēvam, piemēram, vecāku pabalsta saņemšanu un tiesības izmantot bērna kopšanas atvaliinājumu gan vienam, gan otram bērna vecākam, dalītu atvalinājumu, elastīgu darba laiku u. tml. Gan periodā, kad Latvija atradās PSRS sastāvā, gan arī patlaban, ņemot vērā gimenes atbalsta politikā izvirzītos mērḳus, manuprāt, Latvijai, it īpaši kopš neatkarības atjaunošanas, ir aktuāla dzimstības veicināšana un atbalsts ǵimenēm bērnu audzināšanā, jo paaudžu maiņas rādītāji ir vieni no zemākajiem Eiropā un attīstìto valstu kopumā. Latvijā isstenotā politika ilgtermiņā ir bijusi ar pronatalistisku ievirzi un vērsta uz dzimstības palielināšanu, tomēr nepietiekoši sekmīga. Tā kā Latvijas ǵimenes politika ir vērsta uz dzimstības, tātad iedzīvotāju ataudzes veicināšanu, ar gimenes politiku saprotama tāda politika, kas vērsta uz gimenes atbalsta veicināšanu, tātad - gimenes atbalsta politika. Šãds termins lietojams, raksturojot Latvijas situāciju patlaban un ņemot vērā arī vēsturiskus aspektus, proti, arī padomju okupācijas perioda beigu posmā galvenais bija pronatalistiskas politikas virziens, ko apliecina arī virkne valdības lēmumu, kas atspoguḷoti darbā.

Franču pētnieki (Math et al., 2009, 39) uzskata, ka pamatā giimenes atbalsta politikas kodolu veido triju veidu pasākumu kopums:

- finansiāls atbalsts ǵimenēm sociālo pabalstu un/vai nodokḷu atvieglojumu veidā, kompensējot papildu izmaksas, kas ǵimenei rodas līdz ar bērna piedzimšanu;

- atbalsts pakalpojumu veidā izglìtības, aprūpes un uzraudzības jomā bērniem dažādā vecumā. Līdzekḷi, ar kuru palīdzību valsts sniedz atbalstu, var būt dažādi - tieša nodrošināšana ar pakalpojumu un/vai subsīdijas pakalpojumu sniedzējiem, bet tāpat iespējams sniegt atbalstu nodokḷu atvieglojumu veidā vai izmaksāt pabalstu, lai palīdzētu segt izmaksas par pakalpojumu;

- apmaksāti bērna kopšanas atvalinājumi un ar bērna aprūpi saistītas sociālās garantijas (maternitātes, paternitātes atvaḷinājumi, bērna kopšanas atvalinājums, apmaksā slima bērna vai bērna ar īpašām vajadzībām kopšanu u. tml.).

Pēc šãdiem principiem ǵimenes atbalsta politika ir veidota visās ES dalībvalstīs, pat ja atkarībā no valsts uzsvars ir likts uz dažādiem aspektiem vai tā ir veidota lielākoties kā sociālā atbalsta, nevis ǵimenes atbalsta politika.

Kopumā gimenes atbalsta politika ir jauna politikas joma arī Latvijā. Kā atsevišķa politikas nozare (sākotnēji bērnu un ǵimenes atbalsta politika, 
vēlāk - bērnu un ǵimenes politika) tā pirmo reizi iekḷauta Ministru kabineta noteikumos "Ministru kabineta kārtības rullis" (2002) nodarbinātības un sociālās politikas jomā. Tās starpdisciplināro raksturu uzskatāmi parāda fakts, ka ǵimenes atbalsta politikas jomas dokumentu izstrādes un īstenošanas stadijās ir iesaistītas lielākā daḷa valsts pārvaldes sektorā esošās centrālās pārvaldes iestādes - ministrijas un to padotības iestādes, veidojot sarežğìtu sadarbības modeli. Faktiski visas politikas jomas un ekonomiskā izaugsme kopumā ietekmē gimenes atbalsta politikas attīstību un vietu valsts un sabiedrības vērtību skalā.

Ģimenes atbalsta politikas kodolu Latvijā pamatā veido iepriekš minētie 3 galvenie elementi - finansiāls atbalsts ǵimenēm, atbalsts pakalpojumu un citu ǵimenei paredzētu pasākumu veidā un bērna kopšanas atvaļinājums, taču kā starpdisciplināra nozare tā cieši mijiedarbojas ar citām politikas jomām un nozarēm (14.2. attēls). Minētais atspoguḷojas visos politikas plānošanas dokumentos, jo lielākā daḷa pasākumu ir īstenojami, tikai sadarbojoties valsts, pašvaldību institūcijām un nevalstiskā sektora pārstāvjiem.

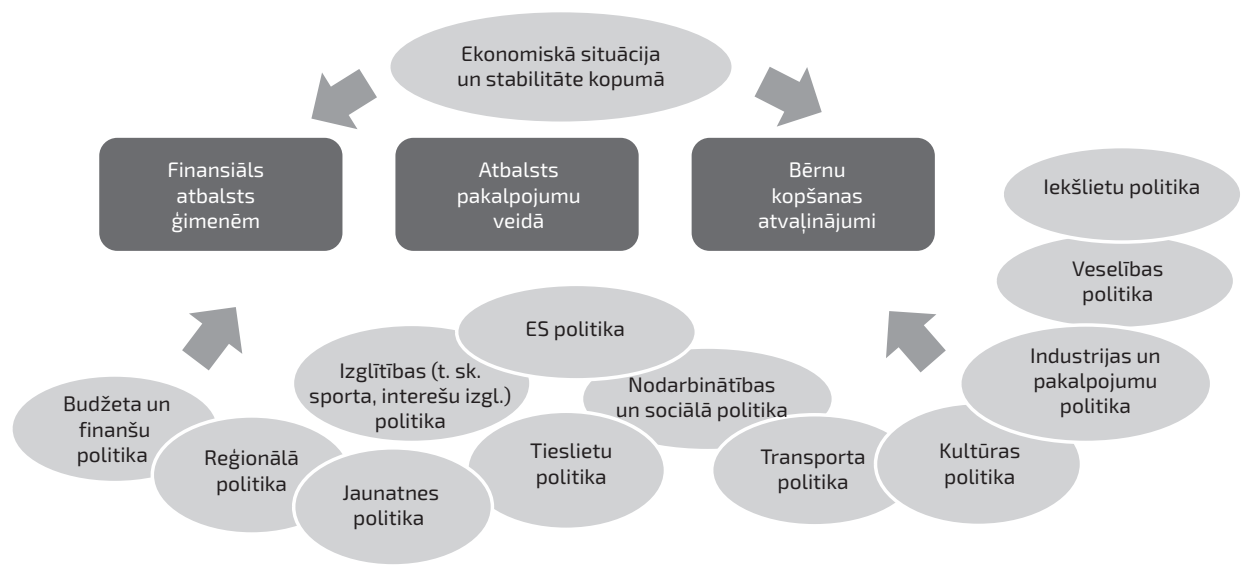

14.2. attēls. G̣imenes atbalsta politikas shēma

Avots: veidojusi autore, n̦emot vērā kopejāas pazīmes visām ES ǵimenes politikām (Math et al., 2009) un Ministru kabineta 07.04.2009. noteikumu Nr. 300 "Ministru kabineta kārtības rullis" noteikto politikas jomu sadalijumu.

Ģimenes atbalsta politikas īstenošana ietver daudzu tās dalībnieku un dažādu līmeņu (valsts, pašvaldības) koordināciju. Tāpēc, lai arī dažkārt ir izstrādātas patiešām labas politikas, pastāv grūtības tās ieviest. Bieži vien trūkst informācijas par jaunieviestiem pasākumiem, tāpēc iedzīvotāji tos neizmanto un negūst labumu no tiem. Piemēram, tiek ieviesti pasākumi vardarbības ǵimenē novēršanai, bet iedzīvotāji nav pietiekoši informēti par tiem, līdz ar to upuri nav informēti par savām tiesībām un pieejamajiem resursiem un tos neizmanto, 
attiecīgi ieviesto politikas iniciatīvu padarot mazrezultatīvu. Tāpat arī resursu trūkums var atturēt no rīcībpolitikas ieviešanas (Robila, 2014, 4). Tāpēc sabiedrības informēšana par atbalsta pasākumiem, izpratnes veidošana un informētas sabiedrības radīšana ir viens no svarīgiem un pastāvīgiem gimenes atbalsta politikas uzdevumiem.

Viens no Latvijas ǵimenes politikas virsmērkiiem ir dzimstības palielināšana. "Deklarācijā par Laimdotas Straujumas vadītā Ministru kabineta iecerēto darbību" bija iecerēts veicināt tautas ataudzi, lai dabiskais pieaugums 2020. gadā sasniegtu pozitīvu vērtību. Tomēr pret šādām prognozēm jāattiecas piesardzīgi, jo demogrāfiskā situācija kopumā, neraugoties uz to, ka pēdējos gados novērojams pastāvīgs dzimstības, arī laulātības, neliels pieaugums, uzlabojas nepietiekami. Deklarācijā nosauktie uzdevumi sasniegti netika, jo L. Straujumas vadītā valdība demisionēja. Arī sekojošajai valdībai (M. Kučinska vadībā) Valsts prezidents R. Vējonis kā vienu no prioritāriem uzdevumiem izvirzīja demogrāfiskās situācijas būtisku uzlabošanu.

ES Pamattiesību harta noteic, ka tiesības stāties laulībā un tiesības veidot ǵimeni tiek garantētas saskaņā ar valsts tiesību aktiem, kas nosaka šo tiesību izmantošanu (ES Pamattiesību harta, 2010). Tādējādi ǵimenes atbalsta politika atrodas katras dalībvalsts ziņā un nav ES kompetencē, tomēr netieši tā ietekmē gimenes atbalsta politikas kodolu. ES var izstrādāt tiesību aktus jomās, kas attiecas uz ǵimenes dzīves saskaņošanu ar darbu, bet sociālie partneri var vienoties par līgumiem, kuri kḷust par direktīvām. Tāpat ES ir platforma ekspertu darbam ar gimenes atbalsta politikas jautājumiem (piemēram, Eiropas Ģimen,u alianses interneta portāls, darba grupa, kas atbild par demogrāfijas jautājumiem u. c.), dalībvalstīm pieejami struktūrfondu līdzekḷi (piemēram, ERAF, ESF) iniciatīvām, kas saistītas ar ǵimenes situācijas uzlabošanu (Eiropas Ekonomikas, 2011, 11). Kā minētajā atzinumā norādījuši Eiropas Ekonomikas un sociālo lietu komitejas eksperti, vispārējā gimenes atbalsta politika ietver fiskālos pasākumus, pabalstus gimenēm, pasākumus vīriešu un sieviešu profesionālās vienlīdzības veicināšanai, pakalpojumus bērnu un aprūpējamu cilvēku atbalsta jomā, ǵimenes tiesības vecuma pensijas sistēmā, kā arī iespēju saskaṇot ğimenes dzīvi ar darbu: var izmantot bērna kopšanas atvalinājumu, izvēlēties nepilnu darbalaiku. Pēc Bogenšneideres domām, ǵimenes atbalsta politika var būt tieša vai netieša. Tieša ğimenes atbalsta politika tiek apzināti veidota, lai sasniegtu specifiskus mērķus, kas vērsti tieši uz ǵimeni kā kopumu un uz ǵimenes locekḷiem (piemēram, bērnu kopšanas atvaḷinājums, vardarbības ǵimenē izskaušana), kamēr netieša ǵimenes politika nav īpaši vērsta uz ǵimeni, taču tā ietekmē ğimeni netieši (piemēram, starptautiskās migrācijas politika).

Latvijā novērojamas abas pieejas - gan tieša ǵimenes atbalsta politika, kas vērsta uz goimenes labklājību (dažādi pabalsti, specifiski nodokḷu atvieglojumi ğimenēm ar bērniem, t. sk. daudzbērnu ğimenēm), gan arī netieša ğimenes 
atbalsta politika (minimālās darba algas un nodokḷu politikas izmaiņas kopumā ietekmē ğimeni).

1990. gada 4. maijā, atjaunojot Latvijas valstisko neatkarību, Latvija pasludināja pievienošanos virknei starptautisko tiesību aktu, tajā skaitā ANO Konvencijai par bērna tiesībām, "Deklarācijai par sociālajiem un tiesību principiem attiecībā uz bērnu aizsardzību un materiālo nodrošinātību, pievēršot īpašu uzmanību aizgādnības un aizbildnības iedibināšanai, kā arī nacionālai un starptautiskai adopcijai" un citiem starptautiskiem cilvēktiesību dokumentiem (Latvijas Republikas Augstākā Padome, 1990). Tas konstitucionālā līmenī noteica tālāko valsts virzību arī ğimenes atbalsta jomā un bērnu tiesību ievērošanā. Tomēr virkne pasākumu ğimenes situācijas uzlabošanai un dzimstības veicināšanai, n̦emot vērā demogrāfisko situāciju kopumā un dzimstību Latvijā, tika veikti jau iepriekš un bija gimenes atbalsta politikas platformas priekšnoteikums. Jau pagājušā gadsimta 70. gadu otrajā pusē, pēc tam, kad 1976. gadā LPSR Ministru Padome izveidoja starpresoru padomi demogrāfisko problēmu izpētei, tika izstrādāts komplekss pasākumu kopums dzimstības veicināšanai nākamajiem desmit gadiem, tomēr šo pasākumu kopumu valdība neapstiprināja (Eglīte, 2013, 51). Drīz pēc tam - 1980. gadā - tapa Latvijas Komunistiskās partijas un LPSR Ministru Padomes lēmums Nr. 304, kas faktiski bija padomju okupācijas perioda pirmais ǵimenes atbalsta politikas plānošanas dokuments Latvijā un paredzēja attīstìt atbalstu vairākos virzienos - gan stiprināt mātes un bērna aizsardzību nodarbinātībā un mājokḷa jautājumos, gan atbalstīt daudzbērnu ǵimenes un ǵimenes stiprināšanas pasākumus. 1983. gadā sāka izstrādāt mērḳprogrammu "Latvijas PSR iedzīvotāji", un tās îstenošana rezultējās dzimstîbas pieaugumā: tika sasniegts dzimstības līmenis, kas nepieciešams vienkāršai paaudžu nomaiņai, pieauga otrā, trešā un nākamo bērnu dzimstība (Zvidriṇš, Eglīte, 1990, 69-72). Savukārt 1987. gadā tika pieņemts jauns valdības lìmeņa dokuments, kas noteica papildu garantiju un priekšrocību (piemēram, ārpuskārtas nodrošināšana ar vietu pirmsskolas izglìtības iestādē, labāka pieejamība ārstniecības, komunālajiem, sadzīves, mājokḷa labiekārtošanas, kultūras un transporta pakalpojumiem) îstenošanu daudzbērnu ǵimenēm un mātēm ar bērniem līdz trīs gadu vecumam.

Tāpat neatkarības atgūšanas priekšvakarā valdībai bija citas, mūsdienās netipiskas problēmas, piemēram, 1989. gada 14. februārī tika pieņemts lēmums Nr. 46 "Par pasākumiem iedzīvotāju skaita nepamatota mehāniskā pieauguma pārtraukšanai un migrācijas procesu regulēšanai Latvijas Padomju Sociālistiskajā Republikā", kas gan primāri bija vērsts uz papildu darbaspēka pieplūduma tempa samazinājumu, bet pastarpināti norādīja gan uz infrastruktūras pārslodzi, nodrošinot iedzīvotājus ar dzīvokḷiem un pārtiku, gan uz infrastruktūru izglītības un veselības vajadzībām. Tādējādi neatkarības atjaunošanas periodā valstī iezīmējās daudz fundamentālāka problemātika, tostarp saistīta ar ekonomikas transformāciju, rubḷa devalvāciju, augsto inflāciju utt. 
Noslēdzoties okupācijas periodam un uzsākot demokrātiskas un suverēnas valsts atjaunošanu, kopējā sociālekonomiskā situācija Latvijā pasliktinājās. Gan pāreja uz tirgus ekonomiku, gan straujais bezdarbs, rūpniecības sabrukums un ekonomiskā krīze lielākajai sabiedrības dal̦ai, tostarp ǵimenēm ar bērniem, izraisīja strauju materiālās situācijas pasliktināšanos. Iedzīvotājiem samazinājās ienākumi, būtiski palielinājās inflācija, vienlaikus ar naudas mainu notika rubla devalvācija, kas visai tieši ietekmēja iedzīvotāju ilgtermiņa uzkrājumus un terminētos mērknnoguldījumus (obligācijas), piemēram, bērnam pēc pilngadības sasniegšanas, kāzām u. tml., padarot tos par nevērtīgiem, tāpēc sabiedrībā pieauga bažas par valsts attīstību, stabilitāti un drošību nākotnē. Ģimenes ar bērniem nonāca situācijā, ar kuru nebija rēķinājušās, kad plānoja un realizēja savas reproduktīvās ieceres. Tas radīja nepieciešamību pēc atbalsta sistēmas un bija priekšnoteikums sociālās palīdzības sistēmas attīstībai Latvijā.

Atbalsta pasākumus ǵimenēm atbilstoši pētnieku (Math, Thevenon, 2009) uzskatam, proti, 3 pamatelementu kopumam (finansiāls atbalsts, bērna kopšanas atvalıinājumi un atbalsts pakalpojumu veidā), laika posmā, kad Latvija attīstījās kā neatkarīga valsts, atsevišķi nodalìt bija sarežǵîti. Tas gan nenozīmē, ka atbalsta sistēma ar ğimenes atbalsta politikai raksturīgajām iezīmēm nepastāvēja. Sociālās drošîbas jomā Latvijā tika īstenota virkne reformu - no haotiskiem, nekoordinētiem gimenes atbalsta elementiem tika izveidota valsts sociālo pabalstu sistēma, kas tika nošķirta no sociālās palīdzības un sociālajiem pakalpojumiem un kas pilnveidoja sociālās apdrošināšanas sistēmu, kura būtiski ietekmēja bērna kopšanas un vecāku pabalstu reformu. Tāpēc autore uzskata, ka ğimenes atbalsta politikas analīzei ir lietderīgi periodu (kopš neatkarības atjaunošanas līdz mūsdienām) iedalīt vairākos laikposmos. Atbilstoši pieņemtajiem tiesību aktiem un politikas plānošanas periodiem no rīcībpolitikas analīzes viedokḷa izšķirami šādi pieci ǵimenes atbalsta politikas attīstības posmi:

1) kopš neatkarības atgūšanas 1990. gadā līdz 1994. gadam, kad pakāpeniski tika izveidota sociālās drošîbas un atbalsta sistēma, kā arī pien,emti normatīvie akti atbilstoši starptautiskajiem cilvēktiesību dokumentiem, kuriem Latvija pievienojās;

2) no 1995. gada līdz 2002. gadam, kad Latvijā bija spēkā likums "Par sociālo palīdzību";

3) no 2003. gada līdz 2008. gadam, kad tika aktivizēta gimenes atbalsta politika, gan pieņemot jaunus progresīvus tiesību aktus un politikas plānošanas dokumentus, kas tieši vai netieši ietekmēja ǵimeni, gan institucionalizējot ǵimenes atbalsta politiku un ieviešot jaunus gimenes atbalsta instrumentus;

4) no 2009. gada līdz 2015. gadam, kad ekonomiskās krīzes ietekmē tika īstenoti pasākumi, kas iespaido ğimenes atbalsta sistēmu, bet, situācijai uzlabojoties, ierobežojumi tika atcelti un ǵimenes atbalsta sistēma atkal aktivizēta; 
5) no 2016. gada jeb ǵimenes atbalsta politikas "pavasaris", kad demogrāfiskās situācijas uzlabošana un gimenes atbalsta politikas pilnveide tika atzìta par vienu no valdības prioritātēm un atsākts mērḳtiecīgs darbs, lai sistēmiski pilnveidotu ǵimenes atbalstu, atvēlot ievērojamus valsts budžeta līdzekḷus mazāk aizsargātām mērkgrupām - aizbildnībā esošiem bērniem, bērniem, kuri zaudējuši vienu vai abus apgādniekus, adoptētājiem, daudzbērnu ğimenēm (sākot ar ceturto bērnu, būtiski pieaudzis ğimenes valsts pabalsts) u. c.

2016. gada pavasarī Ministru prezidenta padotībā izveidota ekspertu sadarbības platforma "Demogrāfisko lietu centrs", kuras eksperti turpina intensīvi strādāt, lai pilnveidotu gimenes atbalsta politiku.

Tomēr jāuzsver, ka g̛imenēm labvēlīga atbalsta politika ir viena no komponentēm, kas pozitīvi iespaido dzimstības līmeni. Pētijumi citviet Eiropas Savienībā neliecina, ka, īstenojot giimenes atbalsta politiku, speciāli pasākumi ǵimenes institūta stiprināšanai spēj ilgtermiñā būtiski ietekmēt dzimstības rādītājus.

Jāatzīst, ka veiksmīgai politikas ieviešanai būtiska ir sistēmas koordinatora kapacitāte - cik lielā mērā pārējās sistēmas sastāvdalas respektē un ieklausās vadošās institūcijas priekšlikumos. Ģimenes valsts politika ir plaša pārnozaru politika, līdz ar to tās koordinējošai iestādei būtu jābūt ar plašākām pilnvarām un ietekmes svirām. Dzimstības veicināšana, nabadzības mazināšana un ğimenes labklājības nodrošināšana kopumā ir viens no svarīgākajiem ilgtermiña valsts attīstības plānošanas uzdevumiem. Lai gimenes valsts politikas īstenošana būtu sekmīgāka, jāpanāk, ka tās pārraudzība tiek uzticēta augstāka līmeņa pārnozaru institūcijai, piemēram, kā tas ir šobrīd, - Ministru prezidenta pakḷautībā esošai iestādei.

\section{Literatūra un avoti}

Blum, S., Rille-Pfeiffer, C. (2010) Major Trends of State Family Policies in Europe. Working Report (April 2010) [https://eldorado.tu-dortmund.de/bitstream/2003/27692/1/EF3_ StateFamilyPolicies.pdf].

Coleman, D. (2006) Immigration and Ethnic Change in Low-Fertility Countries: A Third Demographic Transition. Population and Development Review, 32 (3).

Deklarācija "Par Latvijas Republikas pievienošanos starptautisko tiesību dokumentiem cilvēktiesību jautājumos". Latvijas Republikas Augstākā Padome. Latvijas Republikas Saeimas un Ministru kabineta Zinotäjs, Nr. 21, 1990. g. 24. maijs.

Demeny, P. (2003) Population Policy Dilemmas in Europe at the Dawn of the Twenty-First Century. Population and Development Review, 29 (1): 1-28.

Eglīte, P. (2013) Iedzīvotāju ataudzes veicināšanai domāto pasākumu līdzšinējais iedarbīgums. Grām.: Apcerējumi par Latvijas iedzīvotājiem, Nr. 15. Cilvēka vērtïba un tās skaitliskā izteiksme. Pētnieciskā darba rezultāti. Rīga: SIA LZA Ekonomikas institūts, 168 lpp.

Eiropas Ekonomikas un sociālo lietu komiteja (2011) Atzinums par tematu "Ģimenes politikas loma demogrāfisko pārmaiņu jomā nolūkā popularizēt paraugprakses apmaiṇu dalïbvalstīs". 2011. g. 4. maijs [http://www.lm.gov.lv/upload/sabiedribas_lidzdaliba/demografisko_lietu/materials3_030611.pdf]. 
Eiropas Savienības Pamattiesību harta (2010/C 83/02). Eiropas Savienības Oficiālais Vēstnesis, Nr. C83/389, 2010. g. 30. marts.

Eshleman, R., Bulcroft, R. A. (1991) The Family. Boston: Allyn \& Bacon, 623 p.

Gauthier, A. H. (1999) The Sources and Methods of Comparative Family Policy Research. Comparative Social Research, 18: 31-56.

Lutz, W. et al. (2003) Europe's Population at a Turning Point. Science, 299: 1991-1992.

Math, A., Thevenon, O. (2009) Family Policy Instruments Helping to Cope with Cost of Children. A Report to the European Commission. The Costs of Raising Children and the Effectiveness of Policies to Support Parenthood in European Countries: a Literature Review [http://europa.eu/epic/docs/eu_report_cost_of_children_final_11-05-2009.pdf].

Poston, D. L. Jr., Bouvier, L. F. (2010) An Introduction to Demography. Cambridge University Press, $678 \mathrm{p}$.

Robila, M. (ed.) Handbook of Family Policies Across the World [https://books.google.lv/ books?id=1cM_AAAAQBAJ\&printsec $=$ frontcover\&hl=lv\&source $=$ gbs_ge_summary_r\& $\mathrm{cad}=0 \# \mathrm{v}=$ onepage $\& \mathrm{q} \& \mathrm{f}=$ false $]$.

Schubert, K., Hegelich, S., Bazant, U. (2009) European Welfare Systems. Current State of Research and Some Theoretical Considerations. In: The Handbook of European Welfare Systems. London, pp. 3-28.

Sociālā darba terminologijas vārdnìca (2000) Rīga: "Sociālā darba un sociālās pedagoǵijas augstskola "Attīstība"”. 249 lpp.

Thompson, W. S. (1929) Population. American Journal of Sociology, 34: 959-975.

Zvidriņš, P., Eglīte, P. (1990) Demogrāfiskā situācija un demogrāfiskā politika Latvijā. LPSR ZA Vēstis, 5 (514): 66-74.

Zvidrinšs, P. (red.) (2001) Demogrāfisko terminu skaidrojošā vārdnīca. Rīga: LU, 129 lpp. 